\title{
A study of the zinc deficiency in a section of rural people in Bengal, India by soil fortification
}

\author{
Analava Mitra ${ }^{*}$, Debaprasad B ${ }^{2}$, Tridib K Goswami ${ }^{3}$ \\ 1. Bidhan Chandra Roy Technology Hospital; 2. Department of Chemical Engineering; 3. Department of \\ Agricultural and Food Engineering; Indian Institute of Technology, Kharagpur - 721302, India
}

*Corresponding Author

\section{SUMMARY}

Zinc concentration in the soil of some area in Hoogly is less than normal. Flax seed crop was grown in Zn deficient soil of acid lateritic type. The oil extracted from the oil seed obtained from soil fortified with $\mathrm{Zn}$ contained higher level of $\mathrm{Zn}$ and was fed to persons for judging their biochemical changes with respect to fasting blood sugar (FBS), total cholesterol (TLC), HDL cholesterol (HDLC), LDL cholesterol (LDLC), and triglyceride (TG). The results revealed that feeding flax oil to the volunteers for a period of four years brought considerable changes in lowering down the levels of TLC, LDLC, TG and FBS. However, flax oil with more zinc content has shown more reductions in FBS and LDLC levels. The study tries to find out the relationship between zinc concentration in oil and incidence of non-insulin dependent diabetes mellitus.

[Afr J Health Sci. 2006; 13:53-58]

\section{Introduction}

In Hoogly, a district in West Bengal, India, the occurrence of Non-Insulin Dependent Diabetes Mellitus (NIDDM) is common in a particular pocket in Mogra Block among middle and old age people. In regular diet, consumption of mustard oil and poor quality food is the responsible factor for occurrence of such a disease. Acid laterite soil of this area has zinc concentration below $1.20 \mathrm{ppm}$. As vegetables and plants as a whole get their micronutrient concentration from soil, they are naturally deficient in zinc. Of the various suggestive causes of NIDDM, deficiency of micronutrients, particularly zinc, is believed to be important.

Soil is the main source of nutrients to the plant. But the nutrients are rarely available in adequate quantities in the soil to fulfil the nutritional needs, especially when the high yielding varieties are grown. The nutrients in the soil may be present in insufficient quantities or in chemical combinations, which hinder their availability to the plant. Most soils are either red sandy soils, or black and medium black soils.

Three hormones - insulin, glucagon and somatostatin, basically regulate the homeostatic regulation of nutrient levels in humans. While insulin and glucagon exert diametrically opposite actions so far as glucose regulation is concerned, somatostatin inhibits secretion of insulin and glucagon. X-ray diffraction studies have shown that insulin occurs as a hexameric protein containing two zinc atoms [1].

Zinc is required for normal immune response and taste acuity and enhances the in vitro effectiveness of insulin. Decreased zinc level and hyperzincuria occur in some diabetic subjects and individuals. In NIDDM zinc deficiency occurs in a subset of subjects and play a role in abnormal immune function [2]. Zargar et al. found alterations in trace elements and mineral homeostasis in both IDDM and NIDDM, the later shows vulnerability to moderate zinc deficiency [3]. Plasma insulin-like growth factor 1 is increased with zinc treatment if starting concentrations are less than $165 \mu \mathrm{g} / \mathrm{l}$ but remains unchanged if the values are more [4].

In India, most of the research on $\omega-3$ oil featured fish oils, which are rich in eicosapentaenoic acid (EPA). EPA is manufactured in the body from linolenic acid, which is the primary fatty acid present also in flax oil [5]. Flax oil contains double the amount of $\omega-3$ oil compared to fish oil and is also a good source of linoleic acid as well [6, 7]. In addition, flax oil offers other benefits over fish oil and $\alpha$-linolenic acid (ALA) products $[5,7]$. Flax oil is cheap and, majority of Indians being lactovegetarian, it suits them. The sharp increases in the prevalence of heart diseases and diabetes mellitus 
in India is due to lipid toxicity of unsaturated fats used for cooking [8]. Both Linolenic acid ( $\omega-3)$ and Linoleic acid ( $\omega-6)$, being polyunsaturated fatty acids, promotes oxidation of low-density lipoprotein (LDL) cholesterol and atherogenesis and hence their uses need to be protected by anti-oxidants. Essential fatty acid should be provided to the body for normal tissue functions. Ghafoarunissa established that fat intake was directly proportional to income [9]. The majority of the Indian population is rural based and survive on a meager income; and therefore naturally suffer from chronic energy deficiency due to low fat intake. This condition is also prevalent among the urban poor. The present study aimed at investigating the mode of action of flax oil consumption on biochemical changes in humans.

\section{Materials and Methods}

Flax crop was grown in farmers' field in Mogra Block. The soil of the experimental site is acid laterite, sandy clay loam with $\mathrm{pH} 5.4$, organic carbon $0.4 \%$ and low in nitrogen and phosphorus content [10]. Flax seed was sown during 1997 to 2001 in an area of 3000 sq. meters. The crop received the standard dose of nitrogen, phosphorus and potassium. A portion of the treated plot received $\mathrm{Zn}$ in the form of $\mathrm{ZnSO}_{4}$ applied @ $25 \mathrm{~kg} / \mathrm{ha}$ and the other portion received no zinc treatment [11, 12]. The crop was harvested and the flax seed was extracted from both harvests of treated and untreated plots. The seed was transported after careful inspection (rejecting the bad ones) and oil from the seeds extracted by Ghani (cold process extraction preferred as rise in temperature may degrade the oil) at Balarampur Avoy Ashrama, Kharagpur and preserved in amber coloured containers filled up to the brim and tightly packed by lid. The oil thus prepared was kept ready for immediate consumption. For biochemical study on human beings, 30 NIDDM patients were chosen selectively and were divided into three more or less identical groups of 10 each. The first group acted as a control, the second acted as the volunteer where normal flax oil was given whereas the third group acted as volunteer to whom zinc fortified flax oil was fed. The patients with known renal and hepatic dysfunction and on lipid lowering therapy were excluded from the study. The patients underwent clinical and anthropometrical evaluation before the study. Initial blood samples were analysed for plasma glucose and lipid profile.

The selected persons were traditionally used to consume mustard and groundnut oils in their diet and more of milk fats. Couzy et al] found that zinc absorption was independent of age. The sample persons were fed either flax oil alone or $\mathrm{Zn}$ fortified flax oil for a period of 4 years [13]. Flax is highly prone to oxidation and oxidised lipids are detrimental to health [14]. Therefore the flax oil was fed as per the standard dose - one tablespoonful per day as salad oil mixed with yogurt or cottage cheese or chilli to supply the anti-oxidant required Further, this also masked its insipid taste. The effect of treatment of flax oil in human body was judged based on testing of blood sugar (FBS), total cholesterol (TLC), High Density Lipoprotein Cholesterol (HDLC), Low Density Lipoprotein cholesterol (LDLC) following standard method (15 and use of Photometer 4010, Boehringer, Germany). Very Low Density Lipoprotein cholesterol (VLDLC) was measured as $1 / 5^{\text {th }}$ of Triglyceride value and Low Density Lipoprotein cholesterol (LDLC) was measured by the equation TLC-(VLDLC + HDLC) (Catalogue no.400 971; catalogue no. 543 004, [15]. The readings were taken yearly (at 1 year span from the date of starting the experiment and subsequently at 1 year intervals). The soil sample was collected from $0-15 \mathrm{~cm}$ depth and analysed for $\mathrm{Zn}$ content using Atomic Absorption Spectrometry (AAS) (Shimadzu, Japan, AA-6650).

\section{Results}

\section{Selection of patients}

The patients underwent clinical and anthropometrical evaluation before the study. The characteristics of the patients were:

Sex: $\quad$ Males 22 Females 8

Age: $\quad 47.19 \pm 4.25$ years

Weight: $82.70 \pm 7.02 \mathrm{~kg}$

Body Mass Index $(\mathrm{BMI})=$ Weight $(\mathrm{kg}) /$ Square of height $(\mathrm{m}): 24.46 \pm 1.67$

\section{Zinc content}

The $\mathrm{Zn}$ content of soil was found to be more in treated soil $(1.29 \mathrm{ppm})$ as compared to $1.12 \mathrm{ppm}$ under control treatment where no $\mathrm{Zn}$ was applied. This level of concentration indicates that the $\mathrm{Zn}$ availability in the test soil was in the medium range [16]. The analysis of $\mathrm{Zn}$ in flax oil showed a higher value, that is, $21.02 \mathrm{ppm}$ which was higher than the crop grown on zinc-deficiant soil (19.57 ppm). The higher content of zinc in flax was due to supply of $\mathrm{Zn}$ to the soil and thereby greater availability to the plant. Flax requires fairly high amounts of available zinc for healthy growth and good yields [17].

\section{Biochemical changes in human body}

The flax oil with higher $\mathrm{Zn}$ content when fed to the treated persons, its effect was reflected on changes in biochemical processes of the body. The result revealed that in case of control (person without feeding of flax oil), the biochemical parameters like 
TLC, LDLC, TG and FBS were marginally increased while HDLC gradually decreased over a period of 4 years. Contrary to this, the persons fed with either flax oil or $\mathrm{Zn}$ fortified flax oil showed reverse trend by gradual reduction in levels of TLC, LDLC, TG and FBS with increase in HDLC (Table 1 showing TG and FBS; Table 2 showing TLC, LDLC and HDLC). Analysing TLC, values were $186 \pm 32$ in first year in control patients, which was increased to $196 \pm 32$ after $4^{\text {th }}$ year. The TLC values in patients receiving flax oil were $194 \pm 11$ in the first year and it reduced to $180 \pm 10$ in the $4^{\text {th }}$ year $(\mathrm{p}=0.075)$. In patients receiving zinc fortified flax oil TLC values were $192 \pm 11$ in the first year and this reduced $179 \pm 10$ in the $4^{\text {th }}$ year $(p=0.050)$. Analysing HDLC, values were $48 \pm 12$ in the first year in control patients, which was reduced to $42 \pm 17$ after $4^{\text {th }}$ year. The HDLC values in patients receiving flax oil were $54 \pm 9$ in the first year and it increased to $65 \pm 8$ in the $4^{\text {th }}$ year $(\mathrm{p}=0.050)$. In patients receiving zinc fortified flax oil HDLC values were $53 \pm 9$ in the first year and it increased to $65 \pm 8$ in the $4^{\text {th }}$ year $(\mathrm{p}=0.050)$. Analysing LDLC, values were $110 \pm 26$ in first year in control patients, which was increased to $115 \pm 31$ after $4^{\text {th }}$ year. LDLC values in patients receiving flax oil were $106 \pm 13$ in first year and it reduced to $92 \pm 12$ in $4^{\text {th }}$ year $(p=0.050)$. In patients receiving zinc fortified flax oil LDLC values were $106 \pm 13$ in first year and it reduced to $89 \pm 12$ in $4^{\text {th }}$ year $(\mathrm{p}=0.075)$. Analysing TG, values in control patients were $130 \pm 21$ initially which were increased to $170 \pm 21$. The effects may be due to rural diet [18]. In patients receiving flax oil the initial values were $170 \pm 11$, which were reduced to $105 \pm 13(\mathrm{p}=0.050)$. In the group of patients receiving zinc fortified flax oil initial values of $170 \pm 11$ were reduced to $95 \pm 13$ in $4^{\text {th }}$ year $(\mathrm{p}=0.025)$. Analysing FBS, values in control patients were $152 \pm 20$ initially which were increased to $154 \pm 12$ in $4^{\text {th }}$ year. In patients receiving flax oil the initial values were $123 \pm 12$, which were reduced to $107 \pm 13$ ( $\mathrm{p}=0.075$ ). In the group of patients receiving zinc fortified flax oil initial values of $112 \pm 12$ were reduced to $96 \pm 13$ in $4^{\text {th }}$ year $(\mathrm{p}=0.025)$. As rural diet has no beneficial effects in patients with non-insulin dependent diabetes [18], changes in the biochemical process was brought by consumption of flax oil. Similar observations regarding TG and FBS values have been recorded by Cunnane and Thompson [19].

Table 1. Effect of flax oil on changes in bio-chemical parameters human body (TG and FHS)

\begin{tabular}{|l|l|l|l|l|l|l|}
\hline $\begin{array}{l}\text { Time } \\
(\text { year })\end{array}$ & \multicolumn{2}{|c|}{ TG } & \multicolumn{2}{|l|}{$\begin{array}{l}\text { FBS } \\
(\mathrm{mg} / \mathrm{dl})\end{array}$} \\
\cline { 2 - 7 } & $\begin{array}{l}\text { Control } \\
(\mathrm{mg} / \mathrm{dl})\end{array}$ & $\begin{array}{l}\text { Flax } \\
(\mathrm{mg} / \mathrm{dl})\end{array}$ & $\begin{array}{l}\text { Zn-Flax } \\
\text { Oil } \\
(\mathrm{mg} / \mathrm{dl})\end{array}$ & $\begin{array}{l}\text { Control } \\
(\mathrm{mg} / \mathrm{dl})\end{array}$ & $\begin{array}{l}\text { Flax } \\
(\mathrm{mg} / \mathrm{dl})\end{array}$ & $\begin{array}{l}\text { Zn-Flax } \\
\text { oil } \\
(\mathrm{mg} / \mathrm{dl})\end{array}$ \\
\hline First & $130 \pm 21$ & $170 \pm 11$ & $170 \pm 11$ & $152 \pm 20$ & $123 \pm 12$ & $112 \pm 12$ \\
\hline Second & $150 \pm 24$ & $140 \pm 12$ & $135 \pm 12$ & $152 \pm 17$ & $118 \pm 17$ & $106 \pm 17$ \\
\hline Third & $160 \pm 17$ & $125 \pm 11$ & $115 \pm 11$ & $150 \pm 21$ & $111 \pm 9$ & $100 \pm 9$ \\
\hline Fourth & $170 \pm 21$ & $105 \pm 13$ & $95 \pm 13$ & $154 \pm 12$ & $107 \pm 13$ & $96 \pm 13$ \\
\hline
\end{tabular}

\section{Discussion}

Results showed that zinc has some undoubted effect on blood sugar value in patients of NIDDM and its dyslipidaemic spectrum [20]. In human diabetic subjects and experimental diabetic animals, the activities of all four desaturases are decreased. Of all the four desaturases, $\Delta-9$ desaturase is most affected in diabetes $[21,22,23]$. Studies on the activity of $\Delta-9$ desaturase in human diabetic subjects are lacking. It is however, possible that the decrease in $\Delta-9$ desaturase may also occur in diabetic humans, especially in poorly controlled NIDDM subjects, since insulin plays an important role in desaturation. 
A decrease in $\Delta-6$ desaturase has been suggested on the basis of fatty acid composition as well as direct measurement of the enzyme in diabetic humans [24, $25,26]$. It is a rate -limiting enzyme in the conversion of linoleic acid to arachidonic acid (AA) [27]. Decrease in $\Delta-5$ desaturase in several tissues have also been shown or suggested in diabetic humans [25, 28, 29, 30]. Studies on the activity of $\Delta-4$ desaturase in humans and animals are lacking.
Zinc is essential for the activity of desaturases, and zinc deficiency leads to impaired conversion of linoleic acid to $\gamma$-linolenic acid and subsequent formation of eicosanoids of 1 and 2 series. Zinc toxicity results in nausea to severe vomiting, abdominal pain, lethargy, light-headedness and muscular in-coordination [31] though some workers found no significant effects of zinc in animal studies involving diabetic rats [32].

Table 2. Effect of flax oil on changes in bio-chemical parameters human body (TLC, HDLC, LDLC)

\begin{tabular}{|c|c|c|c|c|c|c|c|c|c|}
\hline \multirow[t]{2}{*}{$\begin{array}{l}\text { Time } \\
\text { (year) }\end{array}$} & \multicolumn{3}{|l|}{$\begin{array}{l}\text { TLC } \\
(\mathrm{mg} / \mathrm{dl})\end{array}$} & \multicolumn{3}{|l|}{$\begin{array}{l}\text { HDLC } \\
(\mathrm{mg} / \mathrm{dl})\end{array}$} & \multicolumn{3}{|l|}{$\begin{array}{l}\text { LDLC } \\
(\mathrm{mg} / \mathrm{dl})\end{array}$} \\
\hline & $\begin{array}{l}\text { Control } \\
(\mathrm{mg} / \mathrm{dl})\end{array}$ & $\begin{array}{l}\text { Flax } \\
(\mathrm{mg} / \mathrm{dl})\end{array}$ & $\begin{array}{l}\text { Zn-Flax } \\
\text { Oil } \\
(\mathrm{mg} / \mathrm{dl})\end{array}$ & $\begin{array}{l}\text { Control } \\
(\mathrm{mg} / \mathrm{dl})\end{array}$ & $\begin{array}{l}\text { Flax } \\
(\mathrm{mg} / \mathrm{dl})\end{array}$ & $\begin{array}{l}\text { Zn- } \\
\text { Flax } \\
\text { Oil } \\
(\mathrm{mg} / \mathrm{dl})\end{array}$ & $\begin{array}{l}\text { Control } \\
\text { (mg/dl) }\end{array}$ & $\begin{array}{l}\text { Flax } \\
(\mathrm{mg} / \mathrm{dl})\end{array}$ & $\begin{array}{l}\text { Zn- } \\
\text { Flax } \\
\text { Oil } \\
(\mathrm{mg} / \mathrm{dl}) \\
\end{array}$ \\
\hline First & $186 \pm 32$ & $194 \pm 11$ & $192 \pm 11$ & $48 \pm 12$ & $54 \pm 9$ & $53 \pm 9$ & $110 \pm 26$ & $106 \pm 13$ & $106 \pm 13$ \\
\hline Second & $190 \pm 38$ & $190 \pm 9$ & $189 \pm 9$ & $46 \pm 12$ & $58 \pm 7$ & $57 \pm 7$ & $114 \pm 17$ & $101 \pm 11$ & $98 \pm 11$ \\
\hline Third & $192 \pm 24$ & $184 \pm 12$ & $185 \pm 12$ & $45 \pm 19$ & $62 \pm 6$ & $61 \pm 6$ & $115 \pm 21$ & $95 \pm 14$ & $92 \pm 14$ \\
\hline Fourth & $196 \pm 32$ & $180 \pm 10$ & $179 \pm 10$ & $42 \pm 17$ & $65 \pm 8$ & $65 \pm 8$ & $115 \pm 31$ & $92 \pm 12$ & $89 \pm 12$ \\
\hline
\end{tabular}

\section{Conclusion}

Flax oil reduces FBS and TG as well as LDLC. The overall effect may be reduction of TLC. Dyslipidaemia is very common in diabetes. Hence, flax oil could be beneficial in management of diabetes. Zinc fortified flax oil show more reduction in FBS and TG level. The study is however inconclusive on the role of zinc in management of diabetes as patients have taken heterogeneous food patterns and performed various unrelated activities during the period of study, which may have some effects in diabetic control.

\section{Acknowledgement}

The authors are deeply indebted to Dr. Arunava Mitra who sponsored the project, the landowners who agreed to cultivate flax and the volunteers of the study. The authors are also indebted to late Prof. S. K. Sawarkar of Department of Chemical Engineering, Indian Institute of Technology,
Kharagpur, India for his valuable suggestions and encouragement throughout the study. The authors are also indebted to Prof. P.B.S. Bhadoria, Prof. B.C. Ghosh and Prof. S. K. Das of Agricultural and Food Engineering Department for their kind suggestions, review and comments. The authors thankfully acknowledge the contributions of Prof. A. K. Nanda and Prof. S. S. Alam of Mathematics Department. The authors were deeply indebted to management and doctors of Balarampur Avoy Ashrama, Kharagpur for their active help and suggestions.

\section{References}

1. Thomas Nogrady. Medical Chemistry, A Biochemical Approach, $2^{\text {nd }}$ Edition. New York: Oxford University Press, 1988 pp294-301.

2. Niewoehner CB, Allen JI, Boosalis M, Levine AS and Mortley JE. Role of zinc supplementation in type 2 diabetes mellitus. The American Journal of Medicine. 1986; 81:63-68. 
3. Zargar AH, Bashir MI, Khan AR, Masoodi SR, Laway BA, Wani AI and Dar FA. Copper, zinc and magnesium levels in fibrocalculous pancreatic diabetes, Experimental Clinical Endocrinology Diabetes. 2000; 108:397-400

4. Blostein-Fuji A, DiSilvestro RA, Frid D, Katz C and Malarkey W. Short-term zinc supplementation in women with non-insulindependent diabetes mellitus: effects on 5'nucleotidase activities, insulin-like growth factor 1 concentration, and lipoprotein oxidation rates in vitro. American Journal of Clinical Nutrition. 1997; 66:639-642.

5. WEM Lands. Fish and human health. New York: Academic Press Incorporation, 1986; pp 136153.

6. KS Gill. Flaxseed. New Delhi: Publications and Information Division, ICAR, Krishi Anusandhan Bhavan, Pusa, 1987; pp300-316.

7. Ching Kuang Chow. Fatty acids in foods and their health implications. New York: Marcel Decker Inc., 1992; p 245.

8. Raheja BS. Increase in heart disease blamed on unsaturated cooking fats. Medical Times. 1999; 29:2.

9. Ghafoarunissa. Fats in indian diets and their nutritional and health implications. Lipids (Supplement). 1996; 31:287-291.

10. US Department of Agriculture. Keys to Soil Taxonomy, $9^{\text {th }}$ Ed. 2003 pp 9-37.

11. Willet Ian. Zinc can make the difference. In Partners in research development, Project 8366, ACIAR Zinc Project in collaboration with ICAR. 1995; pp14-19.

12. Couzy F, Katenmayer P, Mansourian R, Guinchard S, Munoz-Box R and Dirren H. Zinc absorption in healthy elderly humans and the effect of diet. American Journal of Clinical Nutrition. 1993; 58:690-694.

13. Dean Ornish. Program for Reversing Heart Disease. New York: Ivy Books, 1996. pp45-80.

14. Boehringer Mannheim Instruction sheets for manual assays. $\mathrm{GmbH}$ diagnostics Catalogue no.124 095 (cholesterol), diagnostics Catalogue no 543004 (HDLC), diagnostics Catalogue no 124966 (Triglycerides), Catalogue no.263 826 (Glucose), Catalogue no.400 971and catalogue no. 543004 (LDLC). 1983.

15. American Public Health Association. Standard methods for the examination of water and waste water. 1989; pp3157-3164.

16. PN Takkar. Zinc deficiency in Indian soils and crop. In Zinc in Crop Nutrition ( $2^{\text {nd }}$ edition), India Lead Zinc Information Center, Delhi, and International Lead, Zinc Research Organisation
Incorporation. Research Triangle Park, Melbourne. 1991 p 66.

17. Mitra A and Bhattacharya D. Effects of overall consumption, dietary patterns, cooking, on patients suffering from Non insulin dependent diabetes mellitus. Journal of Interacademicia. 2005; 9:635-642.

18. SC Cunnane and LU Thompson. Flaxseed in human nutrition. Illinois: A.O.C.S. Press, 1995. pp157-205.

19. Ohly P, Dohle C, Seissler J, Abel J and Gleichmann H. Zinc sulphate induces metallothionein in pancreatic islets of mice and protects against diabetes induced by multiple low doses of streptozotocin. Diabetologia. 2000; 43:1020-1030.

20. Gellhorn A and Benjamin W. The intracellular localization of an ENZYMATIC enzyme defect of lipid metabolism in diabetic rats. Biochim Biophysics Acta. 1964; 84:167-182

21. Friedmann N, Gellhorn A and Benjamin W. Synthesis of arachidonic acid from linoleic acid in vivo in diabetic rats. Israel Journal of Medical Science. 1966; 2:677.

22. Eck MG, Wynn JO, Carter WJ and Faas FH. Fatty acid desaturation in experimental diabetes mellitus. Diabetes. 1979; 28:479-485.

23. Tilvis RS and Miettinen TA. Fatty acid compositions of serum lipids, erythrocytes, and platelets in insulin-dependent diabetic women. Journal of Clinical Endocrinology Metabolism. 1985; 61:741-745.

24. Jones DB, Carter RD and Mann JI. Indirect evidence of impairment of platelet desaturase ensymes in diabetes mellitus. Hormone Metabolism Research. 1986; 18:341-344.

25. Tilvis RS, Helve $\mathrm{E}$ and Miettinen TA. Improvement of diabetic control by continuous subcutaneous insulin infusion therapy changes fatty acid composition of serum lipids and erythrocytes in type 1 (insulin-dependent) diabetes. Diabetologia. 1986; 29:690-694.

26. Marcel YL, Chrristiansen K and Holman RT. The preferred metabolic pathway from linoleic acid to arachidonic acid in vitro. Biochim Biophysics Acta. 1968; 164:25-34.

27. Stone KJ, Willis AL, Hart M, Kirtland SJ, Kernoff PB and McNicol GP. The metabolism of dihomo- $\gamma$-linolenic acid in man. Lipids. 1979; 14:74-80.

28. Boustani SEl, Descomps B, Monnier L, Wsrnant J, Mendy $F$ and Crastes de Paulet A. In vivo conversion of dihomogamma linolenic acid into arachidonic acid in man. Progress in Lipid Research. 1986; 25:67. 
29. Boustani SEI, Causses JE, Descomps B, Monnier L, Mendy F and Crastes de Paulet A. Direct in vivo characterization of delta 5 desaturase activity in humans by deuterium labeling: effect of insulin. Metabolism. 1989; 38:315.

30. Mondal AK and Jennette JC. Diagnosis and Management of Renal Disease and Hypertension. Philadelphia: Lea \& Febiger, 1988. pp186-189.

31. Brandao-Neto J, da Silva CA, Figueiredo NB, Shuhama T, da Cunha NF, Dourado FB and Naves LA. Lack of acute zinc effects in glucose metabolism in healthy and insulin-dependent diabetes mellitus patients. Biometals. 1999; 12:161-165. 